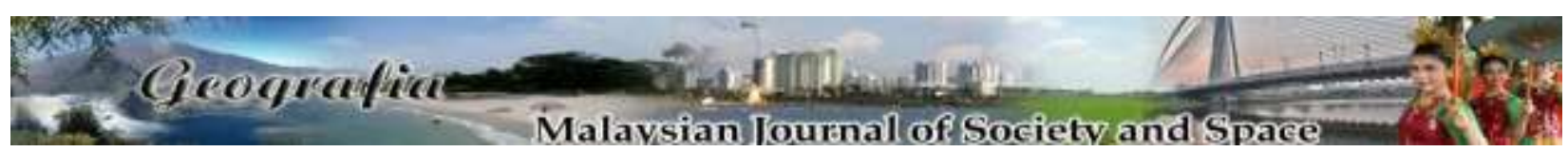

\title{
Opportunity recognition in immigrant entrepreneurship through social capital and geographical proximity: A conceptual framework
}

\author{
Nurul Atasha Jamaludin, Zizah Che Senik, Hamizah Abd Hamid, Nur Sa'adah Muhamad \\ Faculty of Economics and Management, Universiti Kebangsaan Malaysia \\ Correspondence: Nurul Atasha Jamaludin (email: nurulatasha.jamaludin@gmail.com)
}

Received: 22 February 2020; Accepted: 05 August 2020; Published: 28 August 2020

\begin{abstract}
The purpose of this paper is to present a conceptual framework of the role of social capital as an ultimate resource for immigrant entrepreneurs in recognising entrepreneurial opportunities. Research consistently reveals that immigrants have higher tendency to engage in entrepreneurial activities in countries where they reside. Based on a review of existing literature, resources such as human, social, and financial capital facilitate immigrants to pursue entrepreneurial activities. In recognising business opportunities, social contexts have immensely influenced the entrepreneurial process. However, the role of social capital as an ultimate resource for immigrant entrepreneurship have yet to be comprehensively understood. Social capital is significantly related to the information flows, the trust and norms between individuals. Additionally, the geographical proximity between immigrants and their co-ethnic groups and local communities which enable more rigorous social exchanges plays prevalence role for immigrants to pursue entrepreneurial activities. Therefore, we could argue that the social capital and immigrant entrepreneurs' geographical proximity are crucial constructs for immigrant entrepreneurs to recognise opportunities for their business ventures in a host country. The review of past literature enables us to develop a conceptual framework on how social capital and geographical proximity may assist the opportunity recognition of immigrant entrepreneurs. The proposed conceptual framework offers three general propositions than can be empirically validated in future research. This paper contributes to enhance the understanding of immigrant entrepreneurship from the lens of opportunity recognition, social capital and geographical proximity.
\end{abstract}

Keywords: conceptual framework, host country, immigrant entrepreneurship, opportunity recognition, geographical proximity, social capital

\section{Introduction}

The influence of immigrants in the area of entrepreneurship has noticable impacted the society due to globalization (Nazareno, Zhou, \& You, 2018). Many researchers (Aldrich \& Waldinger, 
GEOGRAFIA Online ${ }^{\mathrm{TM}}$ Malaysian Journal of Society and Space 16 issue 3 (94-107)

(C) 2020, e-ISSN 2682-7727 https://doi.org/10.17576/geo-2020-1603-08

1990; Aliaga-Isla \& Rialp, 2013; Fairlie \& Lofstrom, 2015; Griffin- el \& Olabisi, 2018) in various fields such as sociology, economics, and management have linked their studies on immigrants with entrepreneurship. Immigrant entrepreneurship is also a heavily discussed topic in media as well as in public debate (The Economist, 2012; The Wall Street Journal, 2016a, 2016b).

Global immigrants not only fill critical labour shortages but also play a part in creating jobs as entrepreneurs (United Nations, 2015). Through investments and venture creation, immigrants can become a major source of job creation in the host country. They also contribute greatly towards the country's GDP apart from creating jobs for local workers and introducing a variety of product and services (Bates, 1999: Rahmandoust, Ahmadian, \& Shah, 2011). Hence, economic activities performed by immigrants through their venture creation is a huge potential source of entrepreneurial and economic stimulus for the host country. Favourable policies such as special visas for immigrant entrepreneurs to open up business in their countries as practiced by Australia (Wang \& Warn, 2018) and Canada (Rahman, 2018) facilitate immigrants to contribute to the economic growth in host countries as well as home countries (United Nations, 2017).

Immigrant entrepreneurs recognise business opportunities before they establish their business ventures. Shane and Venkataraman (2000) suggested that the early stage entrepreneurship model starts with how opportunities are perceived, acted upon that leads to new venture creation. A model by Cooper (1993) describes the factors affecting the recognition of opportunities for new ventures which include human capital, social capital, the environment, the characteristics and process of the emergent venture, and the characteristics of entrepreneur. In the latest review of immigrant entrepreneurship model, Dheer (2018) proposed three forms of capital prominently discussed in the immigrant literature which are human capital, social capital, and financial capital.

Business opportunities are recognised differently between native and immigrant entrepreneurs. Inevitably, it is argued that financial capital does not influence immigrant to recognise business opportunities (Vinogradov \& Jørgensen, 2017) rather, cross-cultural experience does impact the recognition of business opportunities (Vandor \& Franke, 2016). Another argument emphasizes that human and social capital influence the establishment of business ventures (De Clercq, Lim, \& Oh, 2013; Sahasranamam \& Nandakumar, 2018). Although immigrants lack of financial capital, social capital may trigger immigrants to start the business (Portes \& Sensenbrenner, 1993; Ram, Theodorakopoulos, \& Jones, 2008). The relationship between the actors and their networks could help them to access to the necessary resources (Dana, Gurau, Light, \& Muhammad, 2020; Nahapiet \& Ghoshal, 1998). In order to establish new ventures and to sustain businesses in a host country, immigrant entrepreneurs require access to resources and information such as the strategic supplies of resources, the availability of local workers, and the capabilities to fulfil the customers need, which can be attained through social capital (e.g., Tata \& Prasad, 2015; Dheer \& Lenartowicz, 2018; Shinnar \& Nayir, 2019).

According to Tata and Prasad (2015), three sources of social capital may affect the immigrants' business establishment grouped as (1) friends, acquaintances and family members; (2) ethnic group membership and community; and (3) the host society. Previous findings claim that co-ethnic social capital can be beneficial for entrepreneurs as well as an aid for new immigrants to networking (Guercini, Milanesi, \& Ottati, 2017; Robertson \& Grant, 2016; Wang $\&$ Warn, 2018). This is more significant to immigrants who lack access to family members and 
human capital (Nee \& Sanders, 2001; Tienda \& Raijman, 2004). Apparently, the ties with the coethnic groups is considered as a strong factor where they can offer advice and information about available opportunities in the host country (Bates, 1997). Thus, we argue that social capital as a critical resource for immigrant entrepreneurs in recognising entrepreneurial opportunities leading to the better chances to establish business ventures in a host country.

Just as important, geographical proximity with co-ethnic business ventures enable to advance social interaction thus strengthen immigrant entrepreneurs' social capital (Aldrich \& Zimmer, 1986; Kalnins \& Chung, 2001). In general, ethnic minority typically clusters in one area thus encourage the establishment of business venture (Vries, Hamilton, \& Voges, 2015). Subsequently, neighbourhoods with high incorporation of immigrant populations tend to have similar needs and ethnics demands are manifest as a prosperous territory for immigrant business (Kloosterman \& Van Der Leun, 1999). Kalnins and Chung (2006), argue that the existing coethnic immigrants in a host country with accessible resources are willing to share required resources needed by new entrants without any compensation. As a result, immigrant entrepreneurs are able to access to relevant information on potential suppliers and customers (Villena, Revilla, \& Choi, 2011) which in turn, helps them to save cost and upsurge the survival rate of business ventures (Kalnins \& Chung, 2001). Thus, it increases the possibility of immigrant to pursue entrepreneurial activities in a host country (Bird \& Wennberg, 2016). Hence, this paper further argues the geographical proximity plays an important role for immigrant entrepreneurs related to information exchange and access to the resources eventually enhancing the amount and quality of social capital.

All in all, social capital built within a geographical proximity increases the ability of immigrant entrepreneurs to recognise business opportunities in host country. Therefore, conceptualising opportunity recognition through social capital and geographical proximity in the context of immigrant entrepreneurs can open new theoretical and practical perspectives for better understanding and supporting on immigrant entrepreneurship. The purpose of this paper is to propose a conceptual framework that integrates three perspectives namely opportunity recognition, social capital and geographical proximity in the establishment of immigrant-founded business ventures in the host country. The next section will discuss the literature review, followed by the discussion and proposed conceptual framework and the implication and conclusion of the paper.

\section{Literature review}

\section{Immigrant Entrepreneurship}

Migration is the movement of people from one place to another place. Sasse and Thielemann (2005) defines immigrants as “... persons who have been outside their country of birth or citizenship for a period of 12 months or longer" (p. 656). However, the definition of acknowledged immigrant differs by nations which depends on their respective citizenship policies (Anderson \& Blinder, 2015). The immigrants left their countries for certain distinct reasons such as economic reasons, forced (refugees and asylum-seekers), and family factors (Sasse \& Thielemann, 2005). Due to economic conditions, many immigrants end up become entrepreneurs in the host country (Barrett, Reardon, \& Webb, 2001; Feldman, Koberg, \& Dean, 
GEOGRAFIA Online ${ }^{\mathrm{TM}}$ Malaysian Journal of Society and Space 16 issue 3 (94-107)

1991), embarking into immigrant entrepreneurship phenomenon where immigrants create and develop an enterprise and to be self-employed (Barrett \& Vershinina, 2017).

Empirical evidences have shown that immigrants have higher tendency to conduct businesses (Aliaga-Isla \& Rialp, 2013; Chavan \& Taksa, 2017; Crockett, 2013; Fairlie \& Lofstrom, 2015). Immigrant-founded business venture is defined as business ventures that are established by one or more immigrants as key founders (Wadhwa, Saxenian, Rissing, \& Gereffi, 2007). Immigrant entrepreneurs mainly involved in business sectors such as retail and restaurant trades (Engelen, 2002). Their business ventures have enhanced the economy as well as created job opportunities in the host countries (Mas-Verdú, Ribeiro-Soriano, \& Roig-Tierno, 2015).

According to Dheer (2018), in the twentieth and twenty-first century, there are two types of immigrant entrepreneurs which are 'necessity entrepreneurs' and 'opportunity entrepreneurs'. Most immigrant-founded business are necessity entrepreneurs who are usually entrepreneurs with less skills and are in the market for survival (Borjas, 1986) while opportunity entrepreneurs rather see self-employment as a desired alternative as they recognise the availability of opportunities (Ndofor \& Priem, 2011). The necessity entrepreneurs emerged as a response for making a living (Barrett et al., 2001) and seeking for ways to enhance their life (Boyd, 1989).

Eventually, both types of entrepreneurs are different and motivated by their push and pull factor to be self-employed (Bates, 1997; Fairlie \& Meyer, 1996; Yanai, Che Senik, Muhamad, Abd Hamid, \& Jamaludin, 2020). Push factors explain immigrants end up in self-employment as a last resort due to failure to place themselves in the local job market (Feldman, Koberg, \& Dean, 1991). In contrast, pull factors explain immigrants who are in self-employment by choice and by looking at attractive opportunities (Fairlie \& Meyer, 1996). Previous researchers discuss that self-employment is viewed as an attractive pathway for immigrants' economic mobility (Sanders $\&$ Nee, 1996). Due to discrimination in the labour market and intensified with high unemployment rate among the natives, immigrants tended to set up their own business ventures (Van Tubergen, 2005) when they recognised the opportunities.

\section{Opportunity Recognition}

Opportunity is a focal point to entrepreneurial activities. Shane (2003) defines an entrepreneurial opportunity as "a situation in which a person can create a new means-ends framework for recombining resources that the entrepreneur believes will yield a profit" (p. 18). Opportunity recognition is defined as "being alert to potential business opportunities, actively searching, and gathering information about new ideas" (Kuckertz, Kollmann, Krell, \& Stöckmann, 2017 p.92). There are two views on opportunity recognition, one is Schumpeterian view name as opportunity enactment or creation (Alvarez \& Barney, 2007; Schumpeter, 1934) and another one is Kirznier view name as opportunity discovery or identification (Brockman, 2014; Kirzner, 1978, 1997; Shane \& Venkataraman, 2000). Further, Mainela, Puhakka, and Servais (2014) conclude Schumpeterian view as an innovation opportunity and Kirznerian view as an arbitrage opportunity.

To be a successful entrepreneur, individual must possess an ability to sensibly identify and choose the right opportunities and then develop the opportunities (Alsos \& Kaikkonen, 2004). The recognition of opportunities is a significant part of the domain of entrepreneurship research (Shane \& Venkataraman, 2000). Opportunity recognition is a fundamental issue in institutional entrepreneurship where it requires creative groundwork, social networks, and relevant prior experience and useful knowledge (Philips \& Tracey, 2007). On the other hand, 
entrepreneurial experience could facilitate the information process and enable entrepreneurs to be alert with available opportunities (Alsos \& Kaikkonen, 2004). The different sources of entrepreneurship lie in the variation of information related to the preferred opportunities (Shane, 2000). Thus, the opportunity recognition is different among entrepreneurs depending on their previous related experiences (Alsos \& Kaikkonen, 2004). In contrast, Ardichvili and Cardozo (2000) proposed that opportunity recognition does not entail an astonishing level of creativity and necessarily involve a prior knowledge to serve the respective market. It is rather a combination of the entrepreneur's awareness which involved wide-ranging social networks together with the prior knowledge of market accordingly, aimed to solve customer problem. Thus, opportunity recognition requires entrepreneurs' peculiar cognitive process in which social networks is a key antecedent in the pursuit of identifying the opportunity (De Koning \& Muzyka, 1999) and later they make use of their previous experience and knowledge when embarking in the recognition process (Philips \& Tracey, 2007).

People view and perceive things differently, hence Shane and Venkataraman (2000) stated that not all people realize the availability of the opportunity. Subsequently, the development of new ventures can be assumed before they are founded by looking at the individual differences (Shane, 2000). Individual differences including the amount of relevant experience and idiosyncratic prior information (Ardichvili, Cardozo \& Ray, 2003) would lead to a certain level of sensitivity towards any available opportunity and influence entrepreneurs to recognise certain opportunities (Alsos \& Kaikkonen, 2004). For instance, technology might change how the market reacts to the opportunities, therefore it is imperative for individual to perceive and discover entrepreneurial opportunities so that some attractive entrepreneurial opportunities will not be discarded (Shane, 2000).

\section{Social Capital and Geographical Proximity}

Social capital empowers entrepreneur to do their business by abridging the access of various sources of information including potential suppliers and customers. Social capital has been defined as "the goodwill available to individuals or groups that is derived from the structure and content of an actor's social relations" (Adler \& Kwon, 2002, p.23). Earlier, Nahapiet and Ghoshal (1998) illustrated that social capital is "the sum of actual and potential resources embedded within, available through, and derived from the network of relationships possessed by individuals or social units" (p.243). Due to this definition, Prashantham (2006) argues that social capital is significantly related to the flow of information, the building of trust and norms between individuals whether related to business or not. Thus, this study focuses on immigrant entrepreneurs with social capital that affects the process of immigrant entrepreneurial activities specifically at opportunity recognition process.

A model by Cooper (1993) describes the factors affecting the new venture performance to include human capital, social capital, the environment, the characteristics and process of the emergent venture, and the characteristics of entrepreneur. According to Dheer (2018), a significant volume of research related to resource-based in immigrant entrepreneurship, such as human, social, and financial capital has been discussed. Social structure is classified into three dimensions namely: market relations (the exchange of product and services), hierarchical relations (based on the authority obedience for living as well as for spiritual security) and social relations (in which courtesies, favours and aids are expected) (Adler \& Kwon, 2002). They argue that social structures stimulate social relations which in turn generate social capital (Adler \& 
Kwon, 2002). Social capital has two components which are (1) the social relationships that people innately receive through close families and relatives and also foster in a social context; and (2) the potential resources emerged from these relationships which can be maneuvered in pursuing social and economic goals (Li, 2004).

Portes and Sensenbrenner (1993) have identified two types of social capital in immigrant studies which are bounded solidarity and enforceable trust. Bounded solidarity is a reaction to the particular situational event that affect their co-ethnic community hence stipulate the sentiment of solidarity. It could occur in the absence of reward or any punishment. It is unlikely that enforceable trust could happen out of punishment or in anticipation of rewards. The individuals obliged to abide to some societal values in the social structure and expected to be deemed with trust (Coleman, 1988) in order to be a part of the structure as it could benefit them (Portes \& Sensenbrenner, 1993). All in all, both types of social capital are dependent on the community bonding and sense of belonging.

Social capital is also important to the group of membership surrounding the immigrant entrepreneurs such as professional, religious, or social groups (Kalnins \& Chung, 2006). In addition, Tata and Prasad (2015) demonstrate three sources of social capital may affect the immigrants' business establishment categorised as (1) friends, acquaintances and family members; (2) ethnic group membership and community; and (3) the host society. In order to establish and maintain their businesses, immigrant entrepreneurs who possess limited resources are benefited most from their ethnic groups social capital in their host countries (Kalnins \& Chung, 2006; Lincoln, Gerlach, \& Ahmadjian, 1996). Social capital established with local communities has been one of the causes that drives immigrant to be self-employed (Portes \& Sensenbrenner, 1993). The social capital built with local communities create the willingness to assist and support the business ventures of immigrant entrepreneurs (Adler \& Kwon, 2002). In the same vein, Kalnins and Chung (2006) argued that immigrant entrepreneur can recognise entrepreneurial activities from two mechanisms of social structure; first from the relationship of family and relative and second from local and common ethnic backgrounds.

It has been argued that immigrant entrepreneurs rely on their own ethnicity in the establishment of business ventures (Vries et al., 2015). Through social capital with others (coethnic and local communities), the immigrant entrepreneurs will be exposed and visible to new and scarce information, thus they are able to recognise business opportunities (Arenius \& De Clerq, 2005) and able to serve their co-ethnic groups with similar needs and demands (Kloosterman \& Van Der Leun, 1999). In addition, having similar culture and norms and being in geographical proximity, the immigrants can strengthen their social capital with co-ethnic communities which in turn inspire the establishment of immigrant-founded businesses (Perera, Gomez, Weisinger, \& Tobey, 2013). However, the immigrants who less reliance of co-ethnic communities can get support from other immigrant communities to ensure their business venture survival (Zubair \& Brzozowski, 2018).

Among the advantages of immigrants clustering into the geographical proximity are reducing cost in accessing social capital (Herander \& Saavedra, 2005), enhancing survival rate, and obtaining social and cultural benefits (Kalnins \& Chung, 2001). The survival rate of immigrant entrepreneurs can be obtained when they are among co-ethnic immigrant entrepreneurs who owned high-resources business establishments (Kalnins \& Chung, 2006). Next, the conceptual framework on opportunity recognition in immigrant entrepreneurship through social capital and geographical proximity will be discussed and proposed. 
GEOGRAFIA Online ${ }^{\mathrm{TM}}$ Malaysian Journal of Society and Space 16 issue 3 (94-107)

(C) 2020, e-ISSN 2682-7727 https://doi.org/10.17576/geo-2020-1603-08

\section{Discussion and Conceptual Framework}

To become an entrepreneur is to have the capability to grasp favourable and desirable resources that can help to strategise the establishment of business venture. In pursuing entrepreneurial activities, immigrants need to build relationships with relevant networks (Kalnins \& Chung, 2001, 2006; Kloosterman, Van Der Leun, \& Rath, 1998; Tata \& Prasad, 2008, 2015) through social capital which demonstrate the interaction between the actors in their network (Nahapiet \& Ghoshal, 1998). Given that, social capital is a useful aspect of social networks as well as an important mechanism for immigrant entrepreneurs to conduct their entrepreneurial activities (Dheer \& Lenartowicz, 2018; Tata \& Prasad, 2015; Vandor \& Franke, 2016).

The structured social capital can be achieved through specific groups and communities by studying their network which eventually exhibit opportunity recognition. Indisputably, the environment and society surrounding one's residential area serve as stimuli on how opportunities being recognised (Arenius \& De Clercq, 2005). Geographical proximity is vital as a platform to provide rigorous social exchanges for new immigrant-founded business. The proximity of the same industry or business venture with ethnically based groups as proposed by Kalnins and Chung (2001) does contribute to cost saving and enhance the survival rate, as well as obtain social and cultural benefits. Thus, the combination of resource concentration and geographical proximity possessed by those with limited resources appears to nourish vast amount of social capital and allows a business venture to enjoy the benefits of social capital from a group member who can contribute (Kalnins \& Chung, 2006).

Immigrant entrepreneurship is the phenomenon where immigrants create and develop an enterprise to be self-employed (Barrett \& Vershinina, 2017; Dheer, 2018) to survive in the host country (Barrett et al., 2001). The conceptual framework (Figure 1) shows that in recognising business opportunities, social capital with co-ethnic groups and local communities play very important roles for immigrants to establish business ventures. In addition, immigrants also recognise opportunities from friends and relatives that exist within the co-ethnic groups and local communities. Eventually at this stage, the immigrants will interact, create networks, and build relationship with them. Having social capital abilities enable the immigrants to obtain necessary information (Aldrich \& Zimmer, 1986; Kalnins \& Chung, 2001; Nakhaie, Lin, \& Guan, 2009) for their immigrant-founded business. The wide-ranging conserved social networks through coethnic groups and local communities can expose immigrants to more potential business opportunities (Singh, Hills, Lumpkin, \& Hybels, 1999).

As can be seen in Figure 1, the conceptual framework emphasizes on the importance of geographical proximity with others in the host countries. It is proven that social capital with coethnic and local communities within geographical proximity enable immigrants to establish business ventures (Vries et al., 2015) in the host countries. Indeed, some existing co-ethnic immigrants are willing to share required resources (tangible and intangible) needed by new immigrant-founded business with nothing in return (Kalnins \& Chung, 2006). With the social capital abilities, the required resources can be gained through the exchange and combination of knowledge, which can result in creating new knowledge (Nahapiet \& Ghoshal, 1998). Evidently, social networks are the most substantial and useful source of knowledge and information for entrepreneurs (Johannisson, 1990) to pursue business ventures. Ultimately, the geographical proximity helps immigrant entrepreneurs to reduce costs in accessing resources as in social capital (Herander \& Saavedra, 2005). Indeed, by locating proximately, the mobilisation of resources can be obtained easily and the immigrant entrepreneurs can be exposed and recognised 
to more feasible opportunities to be exploited. Indisputably, the condition and milieu of geographical proximity makes it possible for the establishment of immigrant-founded business.

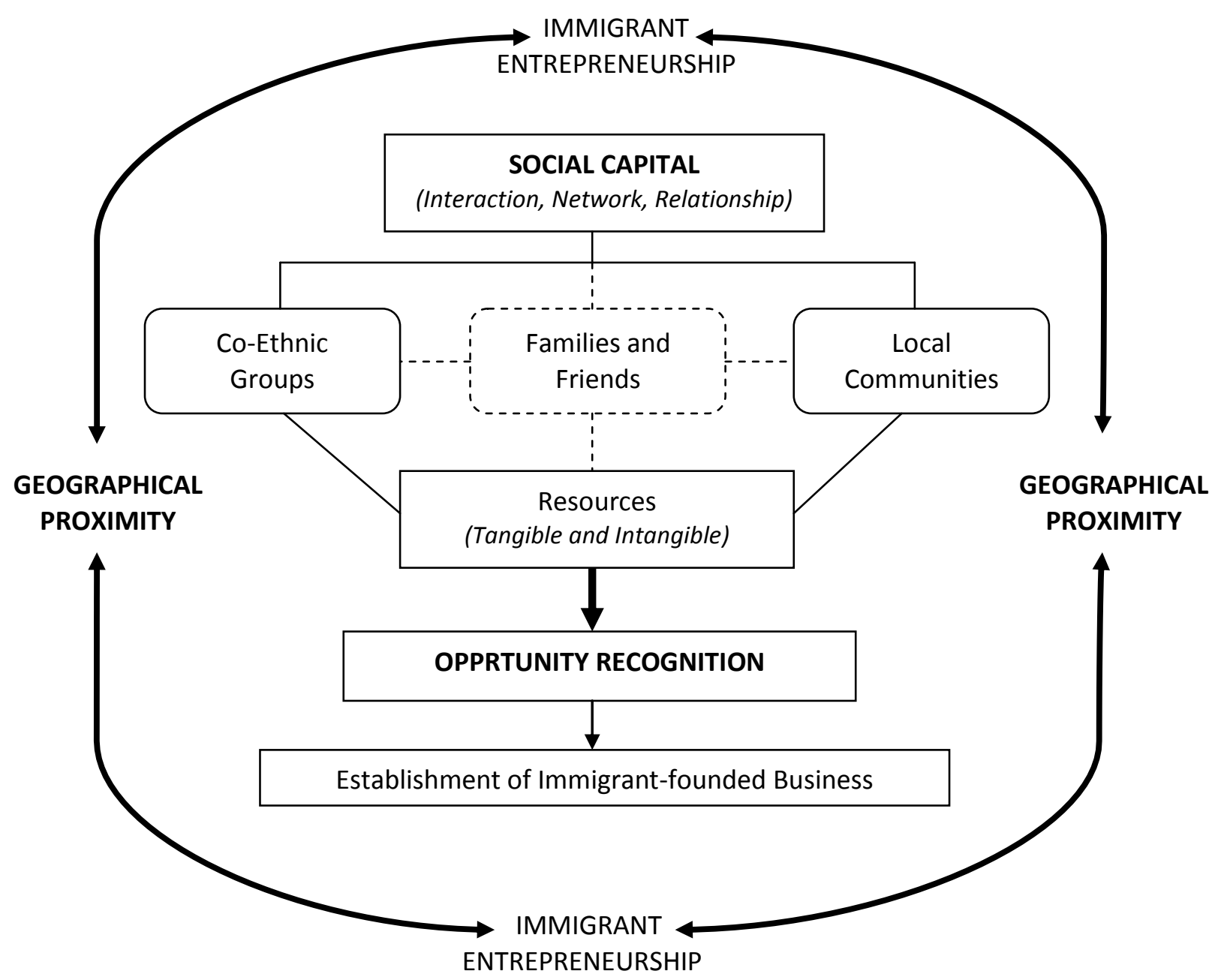

Figure 1. Conceptual framework of opportunity recognition, social capital and geographical proximity of immigrant entrepreneurship

Based on the above discussion, this paper offers three general propositions: (1) in recognising opportunities, immigrant entrepreneurs need to develop social capital with co-ethnic and also local communities by frequently interact with them so that they could access to needed resources in the host country; (2) social capital combined with geographical proximity enable the immigrant entrepreneurs to access to needed resources from the co-ethnic and local communities; (3) social capital accessed within the geographical proximity enable the establishment of immigrant-founded business in host countries. 


\section{Implication and Conclusion}

This paper proposes the conceptual framework on how opportunities being recognised by immigrant entrepreneurs through the lens of social capital and geographical proximity has achieved its purpose. The discussions provide the future researchers to validate the proposed framework and it could benefit the native entrepreneurs as well as to the policy makers. The earlier can gain valuable insight into the importance of social capital and geographical proximity in recognising opportunities of the immigrant entrepreneurs thus they could adapt their best approaches. As for the policy makers, the conceptual framework may assist them in envisage pertinent and effective programs to support entrepreneurial activities in Malaysia.

The proposed conceptual framework attempts to shed light on the importance of the geographical proximity among the immigrants with the individuals (co-ethnic groups and local communities) who owned the resources (tangible and intangible) needed by the immigrant entrepreneurs. The proximity enables them to interact regularly thus developed and strengthen the social capital. Accordingly, trust could be developed (Coleman, 1988) and it appears that geographical proximity affect the resources mobilisation such as expedite information gathering (Ozgen \& Baron, 2007), regularly able to scan the environment (Fiet, 2002) and communicating about business opportunities (Dimov, 2007). Hence, the proposed conceptual framework emphasizes the influence of the geographical proximity between the immigrants and their surrounded communities could deliver more relevant information and knowledge through social capital ultimately recognise the available opportunity.

The limitation of this paper is on the entrepreneurial opportunity process that predominantly consists of three stages which are opportunity recognition, opportunity evaluation and opportunity exploitation. However, this paper only considered the first stage of entrepreneurial opportunity process which was opportunity recognition thus, the paper lacks of inclusive perspectives of entrepreneurial opportunity process. Future research should validate this proposed conceptual framework. In addition, future researchers must consider the three stages of the entrepreneurial opportunity process so that in-depth understanding of the immigrant entrepreneurship with social capital and the geographical proximity can be better comprehended.

\section{Acknowledgement}

The authors acknowledge the financial supports of UKM's Research Grants GUP-2020-002, GGPM-2017-003 and GGPM-2018-023 to facilitate this study.

\section{References}

Adler, P.S., \& Kwon, S.W. (2002). Social capital: Prospects for a new concept. Academy of Management Review, 27(1), 17-40.

Aldrich, H.E., \& Zimmer, C. (1986). Entrepreneurship through social networks. California Management Review.

Aldrich, H.E., \& Waldinger, R. (1990). Ethnicity and entrepreneurship. Annual Review of Sociology, 16(1), 111-135. 
Aliaga-Isla, R., \& Rialp, A. (2013). Systematic review of immigrant entrepreneurship literature: Previous findings and ways forward. Entrepreneurship and Regional Development, 25(910), 819-844.

Alsos, G.A., \& Kaikkonen, V. (2004). Opportunities and prior knowledge: A study of experienced entrepreneurs. Frontiers of Entrepreneurship Research, (March), 301-314.

Anderson, B., \& Blinder, S. (2015). Who counts as a migrant? Definitions and their consequences. Migration Observatory Briefing, COMPAS (Vol. 4). UK.

Ardichvili, A., \& Cardozo, R.N. (2000). A model of the entrepreneurial opportunity recognition process. Journal of Enterprising Culture, 8(2), 103-119.

Ardichvili, A., Cardozo, R., \& Ray, S. (2003). A theory of entrepreneurial opportunity identification and development. Journal of Business Venturing, 18(1), 105-123.

Arenius, P., \& De Clercq, D. (2005). A network-based approach on opportunity recognition. Small Business Economics, 24(3), 249-265.

Barrett, C.B., Reardon, T., \& Webb, P. (2001). Nonfarm income diversification and household livelihood strategies in rural Africa: Concepts, dynamics, and policy implications. Food Policy, 26, 315-331.

Barrett, R., \& Vershinina, N. (2017). Intersectionality of ethnic and entrepreneurial identities: A study of post-war Polish entrepreneurs in an English city. Journal of Small Business Management, 55(3), 430-443.

Bates, T. (1997). Financing small business creation: The case of Chinese and Korean immigrant entrrepreneurs. Journal of Business Venturing, 12(2), 109-124.

Bates, T. (1999). Existing self-employment: An analysis of Asian immigrant-owned small businesses. Small Business Economics, 13, 171-183.

Bird, M., \& Wennberg, K. (2016). Why family matters: The impact of family resources on immigrant entrepreneurs' exit from entrepreneurship. Journal of Business Venturing, 31(6), 687-704.

Borjas, G. (1986). The earnings of state government employees in the United States. Journal of Urban Economics, 19, 156-173.

Boyd, M. (1989). Family and personal networks in international migration: Recent developments and new agendas. International Migration Review.

Brockman, B. K. (2014). Entrepreneurial alertness in opportunity identification and opportunity development. Journal of Business \& Entrepreneurship, 26(2), 27-44.

Chavan, M., \& Taksa, L. (2017). Shifts in intergenerational mobility of Indian immigrant entrepreneurs. International Migration, 55(1), 99-127.

Coleman, J.S. (1988). Social capital in the creation of human capital. American Journal of Sociology, 94, 95-120.

Cooper, A.C. (1993). Challenges in predicting new firm performance. Journal of Business Venturing, 8, 241-253.

Crockett, D.R. (2013). Immigrant entrepreneurs' selectivity: Host market distance and opportunity. Journal of Enterprising Communities: People and Places in the Global Economy, 7(3), 196-212.

Dana, L.P., Gurau, C., Light, I., \& Muhammad, N. (2020). Family, community, and ethnic capital as entrepreneurial resources: Toward an integrated model. Journal of Small Business Management, 1-27. 
De Clercq, D., Lim, D.S., \& Oh, C.H. (2013). Individual-level resources and new business activity: The contingent role of institutional context. Entrepreneurship Theory and Practice, 37(2), 303-330.

De Koning, A.J., \& Muzyka, D.F. (1999). Conceptualizing opportunity recognition as a sociocognitive process. SSE/EFI Working Paper Series in Business Administration, 1-26. Retrieved from http://swoba.hhs.se/hastba/papers/hastba1999_013.pdf

Dheer, R.J.S. (2018). Entrepreneurship by immigrants: A review of existing literature and directions for future research. International Entrepreneurship and Management Journal, 160.

Dheer, R.J.S., \& Lenartowicz, T. (2018). Career decisions of immigrants: Role of identity and social embeddedness. Human Resource Management Review, 28(2), 144-163.

Dimov, D. (2007). "From opportunity insight to opportunity intention: The importance of personsituation learning match". Entrepreneurship Theory and Practice, 31(4), 561-583.

Engelen, E. (2002). How innovative are Dutch immigrant entrepreneurs? Constructing a framework of assessment. International Journal of Entrepreneurial Behavior \& Research, $8(1 / 2), 69-92$.

Fairlie, R.W., \& Meyer, B.D. (1996). Ethnic and racial self-employment differences and possible explanations. The Journal of Human Resources, 31(4), 757-793.

Fairlie, R.W., \& Lofstrom, M. (2015). Immigration and entrepreneurship. In Chiswick, B.R. \& Miller, P.W. (Eds.), Handbook of the Economics of International Migration 1 (pp. 877911). North-Holland: Elsvier.

Feldman, H.D., Koberg, C.S., \& Dean, T.J (1991). Minority small business owners and their paths to ownership. Journal of Small Business Management, 29(4),12-27.

Fiet, J.O. (2002). The systematic search for entrepreneurial discoveries. ABC-CLIO.

Griffin- el, E.W., \& Olabisi, J. (2018). Breaking boundaries: Exploring the process of intersective market activity of immigrant entrepreneurship in the context of high economic inequality. Journal of Management Studies, 55(3), 457-485.

Guercini, S., Milanesi, M., \& Dei Ottati, G. (2017). Paths of evolution for the Chinese migrant entrepreneurship: A multiple case analysis in Italy. Journal of International Entrepreneurship, 15(3), 266-294.

Herander, M.G., \& Saavedra, L.A. (2005). Exports and the structure of immigrant-based networks: The role of geographic proximity. Review of Economics and Statistics, 87(2), 323-335.

Johannisson, B. (1990). Community entrepreneurship-cases and conceptualization. Entrepreneurship and Regional Development, 2(1), 71-88.

Kalnins, A., \& Chung, W. (2001). Ethnic links, location choice and performance: A test of the rural motel industry. Multiunit Organization and Multimarket Strategy, 18, 1-28.

Kalnins, A., \& Chung, W. (2006). Social capital, geography, and survival: Gujarati immigrant entrepreneurs in the U.S. lodging industry. Management Science, 52(2), 233-247.

Kirzner, I. (1978). The entrepreneurial role in Menger's system. Atlantic Economic Journal, 6(3), 31-45.

Kirzner, I. (1997). Entrepreneurial discovery and the competitive market process: An Austrian approach. Journal of Economic Literature, 60-85.

Kloosterman, R., \& Van Der Leun, J. (1999). Just for starters: Commercial gentrification by immigrant entrepreneurs in Amsterdam and Rotterdam neighborhoods. Housing Studies, $14(5), 659-677$. 
Kloosterman, R., Van der Leun, J., \& Rath, J. (1998). Across the border: Immigrants' economic opportunities, social capital and informal business activities. Journal of Ethnic and Migration Studies, 24(2), 249-268.

Kuckertz, A., Kollmann, T., Krell, P., \& Stöckmann, C. (2017). Understanding, differentiating, and measuring opportunity recognition and opportunity exploitation. International Journal of Entrepreneurial Behavior and Research, 23(1), 78-97.

Li, P.S. (2004). Social capital and economic outcomes for immigrants and ethnic minorities. Journal of International Migration and Integration, 5(2), 171-190.

Lincoln, J.R., Gerlach, M.L., \& Ahmadjian, C.L. (1996). Keiretsu networks and corporate performance in Japan. American Sociological Review, 61(1), 67-88.

Mainela, T., Puhakka, V., \& Servais, P. (2014). The concept of international opportunity in international entrepreneurship: A review and a research agenda. International Journal of Management Reviews, 16, 105-129.

Mas-Verdú, F., Ribeiro-Soriano, D., \& Roig-Tierno, N. (2015). Firm survival: The role of incubators and business characteristics. Journal of Business Research, 68(4), 793-796.

Nahapiet, J., \& Ghoshal, S. (1998). Social capital, intellectual capital, and the organizational advantage. Academy of Management Review, 23(2), 119-157.

Nakhaie, R., Lin, X., \& Guan, J. (2009). Social capital and the myth of minority selfemployment: Evidence from Canada. Journal of Ethnic and Migration Studies, 35(4), 625644.

Nazareno, J., Zhou, M., \& You, T. (2018). Global dynamics of immigrant entrepreneurship. International Journal of Entrepreneurial Behavior \& Research.

Ndofor, H.A., \& Priem, R. L. (2011). Immigrant entrepreneurs, the ethnic enclave strategy, and venture performance. Journal of Management, 37(3), 790-818.

Nee, V., \& Sanders, J. (2001). Understanding the diversity of immigrant incorporation: A forms of capital model. Ethnic and Racial Studies, 24(3), 386-411.

Ozgen, E., \& Baron, R.A. (2007). Social sources of information in opportunity recognition: Effects of mentors, industry networks, and professional forums. Journal of Business Venturing, 22, 174-192.

Perera, B.Y., Gomez, C., Weisinger, J.Y., \& Tobey, D.H. (2013). The role of social capital in the growth and innovation of immigrant-founded enterprises. International Journal of Innovation and Learning, 13(1), 33-49.

Philips, N., \& Tracey, P. (2007). Opportunity recognition, entrepreneurial capabilities and bricolage: Connecting institutional theory and entrepreneurship in strategic organization. Strategic Organization, 5(3), 313-320.

Portes, A., \& Sensenbrenner, J. (1993). Embeddedness and immigration : Notes on the social determinants of economic action. American Journal of Sociology, 98(6), 1320-1350.

Prashantham, S. (2006). Foreign network relationships and the internationalisation of small knowledge-intensive firms. International Journal Entrepreneurship and Innovation Management, 6(6), 542-553.

Rahman, M.M. (2018). Development of Bangladeshi immigrant entrepreneurship in Canada. Asian and Pacific Migration Journal, 27(4), 404-430.

Rahmandoust, M., Ahmadian, S., \& Shah, I.M. (2011). Iranian entrepreneurs in Malaysia: Reasons for their migration. World Applied Sciences Journal, 13(9), 2075-2081.

Ram, M., Theodorakopoulos, N., \& Jones, T. (2008). Forms of capital, mixed embeddedness and Somali enterprise. Work, Employment and Society, 22(3), 427-446. 
Robertson, D.W., \& Grant, P.R. (2016). Immigrant entrepreneurship from a social psychological perspective. Journal of Applied Social Psychology, 46(7), 394-409.

Sahasranamam, S., \& Nandakumar, M.K. (2020). Individual capital and social entrepreneurship: Role of formal institutions. Journal of Business Research, 107, 104-117.

Sanders, J. M., \& Nee, V. (1996). Immigrant self-employment: The family as social capital and the value of human capital. American Sociological Review, 61(2), 231-249.

Sasse, G., \& Thielemann, E. (2005). A research agenda for the study of migrants and minorities in Europe. Journal of Common Market Studies, 43(4), 655-671.

Schumpeter, J.A., (1934). The theory of economic development. An inquiry into profits, capital, credit, interest, and the business cycle. Transaction Publishers.

Shane, S. (2000). Prior knowledge and the discovery of entrepreneurial opportunities. Management Science, 47(2), 205-220.

Shane, S. (2003). A general theory of entrepreneurship: The individual-opportunity nexus. Edward Elgar Publishing.

Shane, S., \& Venkataraman, S. (2000). The promise of entrepreneurship as a field of research. Academy of Management Review 25(1), 217-226.

Shinnar, R.S., \& Nayır, Z.D. (2019). Immigrant entrepreneurship in an emerging economy: The case of Turkey. Journal of Small Business Management, 57(2), 559-575.

Singh, R.P., Hills, G.E., Lumpkin, G.T., \& Hybels, R.C. (1999). The entrepreneurial opportunity recognition process: Examining the role of self-perceived alertness and social networks. Academy of Management Proceedings, (1), 1-6.

Tata, J., \& Prasad, S. (2008). Social capital, collaborative exchange and microenterprise performance: The role of gender. International Journal of Entrepreneurship and Small Business, 5(3/4), 373-388.

Tata, J., \& Prasad, S. (2015). Immigrant family businesses: Social capital, network benefits and business performance. International Journal of Entrepreneurial Behavior and Research, 12(6), 842-866.

The Economist. (2012). Immigrant entrepreneurs: The Chilecon Valley challenge. Retrieved from http:// www.economist.com/node/21564564

The Wall Street Journal. (2016a). Immigration Does More Good Than Harm to Economy, Study Finds. Retrieved from https://www.wsj.com/articles/immigration-does-more-good-thanharm-to-economy-study-finds-1474568991

The Wall Street Journal. (2016b). Trump's immigration policy protested in New York. Retrieved from http://www.wsj.com/articles/trumps-immigration-policy-protested-in-new-york1479073697

Tienda, M., \& Raijman, R. (2004). Promoting Hispanic immigrant entrepreneurship in Chicago. Journal of Developmental Entrepreneurship, 9(1), 1-21.

United Nations. (2015). International migration report. Retrieved from https://www.un.org/en/development/desa/population/migration/publications/migrationrepo rt/docs/MigrationReport2015_Highlights.pdf

United Nations. (2017). International migration report. Retrieved from https://www.un.org/en/development/desa/population/migration/publications/migrationreport/doc s/MigrationReport2017_Highlights.pdf

Van Tubergen, F. (2005). Self-employment of immigrants: A cross-national study of 17 Western societies. Social Forces, 84(2), 709-732. 
Vandor, P., \& Franke, N. (2016). Why are immigrants more entrepreneurial? Harvard Business Review. Retrieved from https://hbr.org/2016/10/why-are-immigrants-more-entrepreneurial

Villena, V.H., Revilla, E., \& Choi, T.Y. (2011). The dark side of buyer-supplier relationships: A social capital perspective. Journal of Operations Management, 29(6), 561-576.

Vinogradov, E., \& Jørgensen, E.J.B. (2017). Differences in international opportunity identification between native and immigrant entrepreneurs. Journal of International Entrepreneurship, 15(2), 207-228.

Vries, H.P., Hamilton, R.T., \& Voges, K. (2015). Antecedents of ethnic minority entrepreneurship in New Zealand: An intergroup comparison. Journal of Small Business Management, 53(sup1), 95-114.

Wadhwa, V., Saxenian, A., Rissing, B.A., \& Gereffi, G. (2007). America's new immigrant entrepreneurs: Part I. Duke Science, Technology \& Innovation Paper(23).

Wang, Y., \& Warn, J. (2018). Chinese immigrant entrepreneurship: Embeddedness and the interaction of resources with the wider social and economic context. International Small Business Journal: Researching Entrepreneurship, 36(2), 131-148.

Yanai, L., Che Senik, Z., Muhamad, N.S., Abd Hamid, H., \& Jamaludin, N.A. (2020). Push and pull factors influencing Thai immigrant entrepreneurs conducting business in Malaysia. Journal of Nusantara Studies (JONUS), 5(2), 19-47.

Zubair, M., \& Brzozowski, J. (2018). Entrepreneurs from recent migrant communities and their business sustainability. Sociologica, 12(2), 57-72. 